\title{
An Overview of Tourism Diversity in Nepal
}

\author{
Minesh Kumar Ghimire
}

\begin{abstract}
Tourism is the most important service industry of Nepal. It provided big opportunities of national development and income to maintain international harmony. It will argue the more descriptive nature of information. The diversity of tourism has a huge benefit of tourism development. The tourism activities in Nepal are different attractions such as adventure, natural, cultural etc. The Airway is means of Tourist Arrival means of Nepal and Average Length of Stay is 12 days.
\end{abstract}

Key Words: Tourism activities, Tourism Opportunities, diversity, Eco-tourism.

\section{Background}

Tourism is one of the important factors in the economic sector of Nepal. It doesn't just create employment opportunities but attracts many international tourists which bring in foreign currency. In this regard, to have more international tourist means to be in more foreign currency and as the exchange rate varies, the foreign currency can be a boon for the economic progress of the country. People working in the tourism industry are the direct beneficiary but the people working in agriculture, airlines, hospital, hotels are the indirect beneficiary. The products from the indirect beneficiary can be promoted via tourism and get to the international market as well. It helps people to understand each other and respect each other which helps to maintain harmony in the country and around the world.

Various relevant policy documents, proceedings of various seminars, study reports and such other documents can be reviewed for extracting secondary information of tourism and how tourism has been influential in the life of people who are dependent on it. The concept of cultural tourism emerged in the 1970s. This form of tourism was recognized by UNESCO study in 1976. A Joint World Bank and UNESCO study in 1976 of the social and cultural impacts of tourism endorsed a gradualist approach to tourism development. The study emphasized that this would be even more important in small countries (De Kadt: 1976)

The dependency paradigm was a reaction to the infusionist paradigm and it found its way into tourism studies in the late 1970s and early 1980s (e g Brittion 1982: Hoivik and Heiberg 1980, Husbands 1981, Matthews 1977). It essentially arose out of dissatisfaction with a diffusion paradigm, after several decades, it increasingly became obvious that tourism did not act as the development agent it was thought to be. Multiplier effects were 
considerably less than expected; the international orientation and organization of mass tourism required high investment costs and led to a high dependency on foreign capital, know-how and management personnel (Bryden 1973; Muller 1984; Oestreich 1977; Pavaskar1982). Other studies indicated that tourism is not a powerful regional development agent. Oppermann (1992b) illustrates how tourism is least important in peripheral regions while the economic and political centers have on above average share of the industry. In particular, the international orientation and organization of mass tourism has several criticisms by supporters of the dependency paradigm.

The paradox arises therefore, where tourism is being used as a tool for the development of the periphery, but the entire organization and control of the industry reside in the core region. This provides an example of organizing the dependence on the core in order to foster development of the periphery (Husbands 1981). In physical, commercial and sociopsychological terms, then tourism in a peripheral economy can be conceptualized as an enclave industry. Tourists' arrival points in the periphery are typically the primary urban centers of ex-colonies, now functioning as political and economic centers of independent countries. On package tours, tourists have transported from international transport terminals to hotels and resorts enclaves. The transport, tour organization and the accommodation passes of their itinerary has been confined largely to formal sector tourism companies; tourists then travel between resort clusters and return to the primary urban areas for departure (Britton 1982). In addition, as Din (1990) already notes, all accommodation or transportation chains are in the hands of the developed countries. Many developed countries have established their own airlines and several of them are very successful. Similarly, some companies in the developed countries have become very prosperous hotel chains that are not only offering accommodation facilities in developing countries but also have both or developed properties in the industrialized countries. Finally, Oppermann suggests that 'perhaps' the most significant limitation of dependency in developing countries (1993).

One exception commonly neglected in the discussion of the dependency paradigm is its domestic aspects. While most researchers automatically equate the core-periphery power relation with industrialized-developing countries there exists another power relation within developing countries, namely between the more developed urban areas and the rural and peripheral region within the country, as Britton already indicated in his model. Urban-based companies are usually the only ones that have enough financially and consequently are the only companies to invest in these regions. As a result, a considerable percentage of spending on peripheral areas is drawn towards the metropolis (Jurczek 1985), reducing the local multiplier effect even further. 


\section{Tourism Statistics in Nepal}

More than four lakh tourists have arrived in Nepal from the year 2000 to 2015. The record was acquired from the Tourism Department of Nepal from their official website. The record shows many tourists visited Nepal each year since 2000 along with the growth rate on an annual basis and it also shows which medium they used to visit Nepal i.e. Air or Land. The data also shows the average length of stay of each year since 2000. The record shows that there's a fluctuation on the tourist number each year. The number of tourist arrivals has been recorded fluctuating in different years. In the year 2000, the total number of tourists who visited Nepal was 463646 which was 5.7\% less than that of the previous year 1999 where the total number of tourists that visited Nepal was 491,504. In the year 2000, among the total visitors 3, 76,914 visited Nepal via air and 86, 72 visited via land. They stayed in Nepal for an average 11.88 days. (MoCTA, 2015)

\section{Objectives}

The general objective of this study is to discuss the Tourism Diversity and important service industry and its diversity of Nepal. The specific objectives are: to find out the importance of the tourism services industry ;to discuss the tourism diversity and to identify the problems and important service industry of Nepal.

\section{Methodology}

The overall research design of this study consists of a combination of various secondary sources. This discussion has been designed to carry out with descriptive and exploratory nature particularly based on qualitative information. Quantitative data has been supportive to carry out the findings of the research.

\section{Results and Discussion: Tourism Activities in Nepal}

Nepal has a wide diversity of natural and cultural resources which gives it a benefit of having a variety of tourism related activities. Activities such as hiking and trekking to sightseeing. Nepal has a wide variety of tourism activities where thousands of tourists enjoy each year. The means of Tourist Arrival in Nepal 2018 - 2019 by Air 2018 (969287) and 2019 (995884) change percentage is 2.67. By Land 2018 (203785) and 2019 (201307) Total arrival in 2018 (1173072) and 2019 (1197191) Average Length of Stay 2018 (12.4) and 2019 (12.7) and average change stay percentage is 2.2. Pleasing activities, extreme activities and sports activities are the popular ones in Nepal. All the tourism activities available in Nepal are described below. 


\section{Trekking and Hiking}

Nepal is one of the best destinations in the world for trekking since it has most of the highest mountains in the world. Trekking to the base camp of those mountains is challenging, adventurous and fun. Each year thousands of tourists come to Nepal with the purpose of trekking to such places where the natural beauty can be seen at its best. Depending upon the level of difficulty, budget of the trekker, days available, and pick seasonal or off seasonal destinations, single or combined in a group activity can be chosen for trekking in various destinations throughout the country. The most popular trekking destinations in Nepal are Everest Base Camp, Annapurna Base Camp, Annapurna Circuit, Poonhill trek, Langtang trek, Manaslu trek, Gokyo trek, upper Mustang trek, upper Dolpo trek, Kanchenjunga trek, Makalu base camp, Rara Lake, Phoksundo lake, Tilicho lake. (Bookmundi, 2015)Along with trekking the other popular choice of tourism activity in Nepal is hiking. Nepal is full of green valley, gorge, beautiful villages, White Water Rivers, lakes, natural sceneries which attracts thousands of tourists for hiking each year. Forests full of varieties of animals, birds, butterflies, insects, reptiles and flowers and trees attract tourists as well. The most popular hiking destinations in Nepal are Nagarkot, Chisapani, Shivapuri, Namo Buddha, Godavari, Amitabha Monastery, Sundarijal, Namo Buddha, Nuwakot, GhaleGaun, Phulchowki, Manakamana, Kulekhani, Daman, Dakshinkali, Kakani, Dhulikhel. (Dev, 2014)

The best treks in Nepal before venturing into the Himalayan country. Infographic showing the best treks in Nepal, including number of trekkers, based on the no. of TIMS card permits issued in 2017.

Table: The trekking route, days and trekker

\begin{tabular}{|c|c|c|}
\hline Everest base camp trek & 12 days & 25000 trekkers/year \\
\hline Annapurna circuit trek & $13 / 15$ days & Annapurna region: +100000 trekkers/year \\
\hline Annapurna base camp trek & $9 / 11$ days & Annapurna region: +100000 trekkers/year \\
\hline Poonhill trek & $4 / 7$ days & Annapurna region: +100000 trekkers/year \\
\hline Langtang trek & $7 / 13$ days & 9000 trekkers/year \\
\hline Manaslu trek & 14 days & 6700 trekkers/year \\
\hline Everest base camp 3 passes trek & $16 / 18$ days & 1800 trekkers/year \\
\hline Gokyo lakes trek & $10 / 12$ days & 1000 trekkers/year \\
\hline
\end{tabular}


Patan Pragya (Volume: 6, Number: 1 2020)

\begin{tabular}{|c|c|c|}
\hline Upper mustang trek & 14 days & 4300 trekkers/year \\
\hline Upper dolpo trek & $21 / 22$ days & 1400 trekkers/year \\
\hline Kanchenjunga trek & 20 days & 1010 trekkers/year \\
\hline Makalu base camp trek & 16 days & 1500 trekkers/year \\
\hline
\end{tabular}

\section{Mountain Climbing}

The northern high rocks of Nepal stretches $800 \mathrm{~km}$, it consists of eight of the 10 tallest mountains in the world including Mount Everest which is the world's highest mountain with an altitude of 8848 meters. Ever since the country opened the doors for people to climb mountains in 1994 it has become the best place in the world to ascend the mountains and feel proud after accomplishment. Many people fail in the attempt to reach the top which has provided the people with impetus of climbing or trying once. Each year thousands of people try to climb these mountains and some of them succeed and some don't but the pure joy of doing these hardcore and adventurous activities has attracted people each year. Some people lose their lives while attempting to conquer these mountains. The most popular mountains that most of the people attempt to climb in Nepal are Mt. Everest, Annapurna, Manaslu, Yala peak, Mera peak, Island peak, Pisang peak.

\section{Mountain Flight}

People who don't have much time or people restricted by time who come to visit Nepal can go for mountain flight which offers the panoramic view of the mountains of Nepal such as Everest, Kanchanjunga and Tibetan Plateau. It gives the closest possible view of these majestic mountains in just an hour long flight. It is one of the most popular activities that tourists opt for in Nepal.

\section{Rafting, Kayaking and Canoeing}

Nepal is the second richest country in water sources in the world in terms of land and water ratio. Nepal has numerous rivers and rivulets, lakes and water sources which offer adventure sports activities such as rafting, kayaking and canoeing. Rafting in the rivers such as Trishuli, Kali Gandaki, BhoteKoshi, Marsyangdhi, Karnali, Sun Koshi are pure fun. Nepal is popular for white water rafting. Trishuli River Rafting which is grade 3 rafting is the most popular one in Nepal. Not only rafting but tourists can go for kayaking as well in these Rivers. Kayaking can be done in the lakes of Nepal as well such as Fewa Lake, Begnas Lake, Rupa Lake. The diverse terrain of Nepal makes it possible for having many waterfalls in Nepal where people can go canoeing. Canoeing is an extreme sport that is popular in Nepal. Thousands of people go canoeing each year. 


\section{Paragliding and Skydiving}

People who are real thriller seekers can go paragliding or skydiving in Nepal. The adrenaline of flying like a bird is a wish of everybody. The majestic tourist destination Pokhara provides these opportunities to those who want to try this. Paragliding takes off from the height of Sarangkot and lands on the bank of Fewa Lake. The commercial paragliding is centralized in Pokhara and some companies are trying to operate out of Pokhara valley. More than 60 companies have operated their service in all over the nation and average 16-18 flights.

\section{Bungee Jumping}

Bungee Jumping In Nepal: 2 Places to See the Adventurous Side of the Country. Situated over 160 meters above BhoteKoshi River, the bungee jump here is majestic and thrilling. Shear drop from the steel suspended bridge towards the blue flowing river and that feeling of adrenaline rush for a few seconds is what the bungee jump in Nepal provides. Another bungee in Nepal is at Pokhara this located near a Tibetan camp at Kaski district, there is a steel cliff from where you will jump. It is as high as 80 meters and there is an artificial pond which is 20 meters deep. 30 to 40 people can indulge in the activity in a day.

\section{Mountain Biking}

The best way to explore Nepal and the beauty of Nepal is to go mountain biking. The rough terrain of Nepal provides the opportunity to ride on the uphill and downhill and on the hardcore road. Mountain biking offers an environment friendly way to explore the beauty of Nepal, be it natural or historical. One can rent a mountain bike and go on a long ride. The best place to ride is in the city areas such as Kathmandu and Pokhara and for those who seek thrill and have a gut, they can ride to the exotic places like Namche Bazar.

\section{Ecotourism}

It is a form of nature tourism (tourism to natural, unspoiled areas) which assumes active promotion of environmental conservation and direct benefits for local societies and cultures, together with the provision for tourists of a positive, educative experience. Ecotourism is a group of sustainable tourism activities occurring in the natural environment. Similarly, the destination is an underworld heritage site and following the guidelines of sustainable tourism for the betterment of the ecological system and rights of flora and fauna considering the destination is ecotourism destination. It is a form of nature tourism (tourism to natural, unspoiled areas) which assumes active promotion of environmental conservation and direct benefits for local societies and cultures, together with the provision for tourists of a positive, educative experience. Ecotourism is a group of sustainable tourism activities occurring in the natural environment. Similarly, the destination is an underworld heritage site and following the guidelines of sustainable tourism for the betterment of the ecological system 
and rights of flora and fauna considering the destination is ecotourism destination. There are lots of potentialities in the destination for the development of eco-tourism. There are large possibilities of ecotourism in nations Like Chitawon, Parsa, Bardiya, Shuklaphata National park. Chitawon National park is the kingdom of ecotourism. Besides this there are other tourism prospects. Some data of the major tourism destination and their location are discussed below;

Table: The tourist of ecotourism DNPWC

\begin{tabular}{|l|l|l|l|l|l|l|}
\hline fiscal Years & $2070 / 71$ & $2071 / 72$ & $2072 / 73$ & $2073 / 74$ & $2074 / 075$ & $2075 / 076$ \\
\hline Protected Area & 558577 & 517094 & 389223 & 604091 & 699552 & 706148 \\
\hline
\end{tabular}

\section{Jungle Safari}

Nepal's rich and unique bio-diversity makes it an ideal place for eco-tourism. The lowlands of Terai are full of tropical jungles which provide a huge variety of wildlife which makes it ideal for jungle safari. Nepal has 9 national parks, 3 wildlife reserves, 6 conservation areas and a hunting reserve which covers the total area of 28,999 square kilometers. This is $19.7 \%$ of the total area of Nepal. Tourists can enjoy the elephant ride, canoe ride, jeep safari, nature walking, bird watching excursions or quick tours around in the jungle areas where they can find tigers, one-horned rhinos, peacocks, different types of deer, wild boar, wild bison, monkeys, bears, wild elephants, leopards, gharials, crocodiles. They can also find aquatic birds alongside the rivers banks. (Mountain Monarch Climbing and Trekking, 2016).The famous areas for jungle safari in Nepal are Chitwan, Bardiya, ShivapuriNagarjuna, khaptad national park.

Wildlife tourism can be broadly defined as trips to destinations with the main purpose of the visit is to observe the local wildlife. Therefore, it implies that wildlife tourism includes other niche markets such as the exploration of wild animals. Wildlife tourism is a journey to destinations with the main purpose of the visit is to observe local fauna.

\section{Rural Tourism}

Rural tourism refers to all tourism activities in a rural area. The destination has values of a rural area and does have various activities related to rural tourism like; Passive Tourism: bird watching, photography, landscape appreciation, and Active tourism: village walk, bicycling etc. Green tourism refers to tourism in the countryside or green areas. It is more commonly used to describe forms of tourism that are considered to be more environment friendly than traditional, mass tourism. In rural areas, green tourism is an important form of rural tourism, and destination is the camouflage of rivers, forest, lakes, and ponds. Green tourism activities are shorter tourism. 


\section{Recreational Tourism}

Recreational activities are often done for enjoyment, amusement, or pleasure and are considered to be "fun". Tower Night stay, Elephant bathing, Safaris, Village Tour are the recreational activities found on destination.

\section{MIEC Tourism}

Nepal is a naturally attractive place for organizing international standard events (Meeting, Incentive, Conference, and Exhibition). Different hotels as well as various convention centers in Kathmandu and Pokhara are famous for providing excellent environment and top graded facilities. Both the cities are well connected with global communication systems, transportation facilities and security management. The international delegates in Nepal can sip the taste of spectacular Himalayan vistas while attending at their business. Hence, Nepal sustains a tremendous possibility of emerging out of a top MICE destination.

\section{Cultural Tourism}

Nepal despite being a small landlocked country presents uniqueness in its socio-cultural diversity and natural beauty. The visitors who come and spend time in different parts of the country have always admired it. The country is very rich in cultural heritage, architecture, temples and monasteries, unique music, dance, literature, painting, sculpture, traditional folk arts, and crafts. Those who have known or heard even a little about Nepal's beauty and culture absolutely adores it. Nepal was also recently listed as the one of the 50 places you should see before you die list published by BBC Holiday.

The traditional heritage has a rich history of Nepal and is one of the most culturally appealing places in the world. Lo Manthang is located in the district of Mustang, which offers a range of cultural experiences most likely walk the direct trade routes from the 15th century, and explore some of the richest Buddhist culture found in the country. Kathmandu Valley is the capital of Nepal, with the surrounding valley containing an impressive number of cultural heritage sites, and the valley has been named a UNESCO World Heritage Site. This area contains a number of sister cities, including Bhaktapur, which was once the country's capital. Rich with beauty and cultural significance, the city of Bhaktapur is teeming with ancient artworks and carvings made from wood, stone and metal. Also within the valley are the temples of Pashupatinath. Sat alongside the sacred Bagmati River, these are some of the most important temples of Lord Shiva in the world, and the oldest temples in Kathmandu.

Lumbini is widely regarded as the birthplace of the Lord Buddha (the Tathagata). Today, a Buddhist pilgrimage centre is being erected, and the site is a favourite among archaeologists. The site is regarded as one of the holiest and most sacred spots in the world, 
and holds a calm serenity that is nonpareil. The predominant source of evidence behind this site's authenticity is the Asoka pillar, which was constructed in 249 B.C. and was discovered in 1896. The pillar testifies this area as the birthplace of Buddha, and its location within the Terai plains make it both naturally and culturally rich.

The city of Janakpur is home to many temples and religious ponds. The city contains some of the most beautiful architecture to be found in Nepal and is surrounded by vast natural beauty. Located here is the JanakiMandir, which is a dedication to the goddess of Sita and stands as Janakpur's oldest temple. The intricate building features incredible details, and is an important example of Rajput architecture. The city is home to more than 100 sacred ponds, such as Ganga Sagar, and traditional artworks from the Maithili women, the origins of which are mysterious and as ancient as the place itself.

Langtang runs very close to the borders of Tibet and China, and is a popular trekking spot. Here, you will find the Tamang Heritage Trail that passes through the historical towns of Goljung, Gatlang, Chilime and Briddim to name just a few. Langtang offers some of the oldest and most traditional Tamang villages, and you will see how people within the oldest tribe of Nepal live. The Gosainkunda Lake is an important religious spot for Hindus, and is said to have been created by Lord Shiva himself. Also here is the village of Briddim, which is a picturesque Tamang settlement.

The Tansen is traditional Newari architectural influences. Due to the town's history as an old trade route between India and Tibet, a large bazaar (MakhanTole) is the town's commercial hub. The town's history dates back to the 11th century AD and is home to a handful of ruins that date between the 15th and 19th centuries. Prominent temples such as the Bhairab Temple

\section{Agro Tourism}

Agro-tourism is the way of responsible and sustainable tourism development. This advanced activity helps to lift up the socio-economic condition of the rural area by creating employment opportunities and the additional markets for the rural product along with helps to preserve traditional culture. Agro-tourism can be an alternative economic element for the country whose economy is largely dependent in agricultural and recreational tourism. The main goal of agro-tourisms is the practice of attracting visitors in the areas which are used for agricultural purposes. Many tourism activities can be added with little additional investment and small changes can result in double benefits and increase the sustainability of the farm.

Last but not least, the Working Farm, Direct Contact, Authentic agritourist (WFDCA) typology refers to activities where tourists fully participate in farm tasks. Visitors work and contribute to the farm economy in return for accommodation and food. There are limited 
opportunities one to experience WFDCAagritourism so there are not many examples discussed in the literature.

\section{Conclusion}

Tourism is an important income source of Nepal. It creates direct and indirect employment opportunities and income foreign currency to maintain harmony in the country and around the world. They stayed in Nepal for an average 11.88 days as well. In this discussion descriptive and exploratory in nature of information. Nepal has a lot of diversity of natural and cultural resources have benefit of variety of tourism activities All the tourism activities available in Nepal are described in different sector and attractions such as Trekking and Hiking, Mountain Climbing, Mountain Flight, Rafting, Kayaking and Canoeing, Paragliding and Skydiving, Bungee Jumping, Mountain Biking, Ecotourism, Jungle Safari, Rural Tourism, Recreational Tourism, MIEC Tourism, Cultural Tourism, Agro Tourism etc. The means of Tourist Arrival in Nepal by Air and road they area Average Length of Stay 2018 (12.4) and 2019 (12.7)

\section{Reference}

Brittion(1982).Hoivik and Heiberg 1980, Husbands 1981, Matthews 1977, Tourism and Development Concepts and Issues: Channel View Publications Clevedon, Buffalo, Toronto, Sydney

CBS, (2006). Nepal in Figures 2006. Government of Nepal, National Planning Commission Secretariat, Central Bureau of Statistics, Kathmandu, Nepal

Constitution of Nepal, 2015, Government of Nepal. Kathmandu.

De Kadt (1976).Tourism, Passport to Development? Perspectives on the Social and Cultural Effects of Tourism in Developing Countries (World Bank Research Publications)

Din (1990). Tourism Growth, Development and Impacts, tourism impacts, planning and management

DNPWC (2017). Annual Report of Department of National Parks and Wildlife Conservation, Babarmahal, Kathmandu.

DNPWC/PPP (1998) Community Based Biodiversity Conservation, Strategy and Operational Framework, Kathmandu Nepal.

Heinen, T.J. and Mehta, J.N.(2000). Emerging Issues in Legal and Procedural Aspect of Buffer

Zone Management with Case Studies from Nepal, Journal of Environment and Development, Vol. 9 No 1. Pp 45-67.

Oppermann 1992, Tourism space in developing countries, Annals of Tourism Research, Theory,DevelopingCountries,Tourism,Models,: ElsevierPublication.

Sharma, U.R. (1991). Park-people Interaction in Royal Chitwan National Park, Nepal, Ph D. Dissertation. University of Arizona, Tucson, USA. Thomoson Business press, 1997.

UNESCO 1976,Case study on the effects of tourism on culture and the environment: Nepal; ChitwanSauraha and Pokhara-Ghandruk, Regional Office for Asia and the Pacific (Thailand) 